\title{
Characteristics of Indonesian Adolescents who had Experienced Pregnancy Under the Age of 20 Years: Basic Health Research 2018
}

\section{Ratih Indraswari')}

${ }^{1}$ Health Promotion and Behavioral Science Section, Faculty of Public Health, Universitas Diponegoro, Semarang, Indonesia

Corresponding directed to e-mail: ratih.indraswari@gmail.com

\begin{abstract}
Background: As well as other countries, Basic Health Research 2018 (Riskesdas) reported that adolescent pregnancies (aged under 20 years) occurred in almost all provinces in Indonesia. More than 60,000 Indonesian females experienced pregnancy at a young age. Objective: This study aims to analyze the characteristics of Indonesian women who had been pregnant under the age of 20 years. Methods: This study used a quantitative study with a cross-sectional design, the data processed was from Indonesian Basic Health Research 2018. The subjects were 67,392 women who experienced their first pregnancy under the age of 20 years. The independent variables of the study included the respondent's domicile, age, education level, and occupation. The dependent variable was the age at first pregnancy. All variables were analyzed using univariate, bivariate, and multivariate analysis. Results: Almost all (95.4\%) Indonesian women who had experienced adolescent pregnancy were in the age range of 14-19 years when they were first pregnant. Most of the respondents lived in rural areas (68.1\%), were in late adulthood (32.9\%) when the survey was conducted, had completed primary school education (38.7\%), and were not working (47.9\%). Domicile, age, education, and occupation were related significantly to the age at which they were first pregnant $(P$-Value $=0.0001)$. Education affected the age at first pregnancy in women with a history of adolescent pregnancy $(O R$ $=2.215$ ). Conclusion: Adolescent with low education level is 2.2 riskier to have early pregnancy than an adolescent with high-level education. The government needs to make it a priority and seriously provide provision of reproductive health education among children before they get into their adolescence phase.
\end{abstract}

Keyword: adolescent, adolescent pregnancy, reproductive health, Riskesdas (Basic Health Research).

\section{INTRODUCTION}

Basic Health Research 2013 and 2018 recorded that women in Indonesia had a history of having their first pregnancy at a very young age $\quad<15$ years). Most of the reasons that caused adolescents to have premarital sex were curiosity (57.5\%) and it happened unplanned (38\%). These reflected the lack of understanding of the adolescents regarding the dangers of having premarital sex and low skills of making healthy decisions (Masni and Hamid, 2018).

Sexual behavior that poses health risks in adolescents is influenced by several factors. Adolescents' access to pornography describing the enjoyment of sex enables them to have sex at an early age (13 to 15 years). Adolescents with low self-esteem have 3.3 times the opportunity to engage in premarital sexual behavior. Premarital sexual behavior is also influenced by the sexual behavior of close friends, religiosity, and attitudes (Wulandari, 2016). National Population and Family Planning Board (BKKBN) reported that $35 \%$ of young men felt no need to maintain their virginity, $10 \%$ of young women felt no need to maintain their virginity, and dating without having sex was considered by $95 \%$ of adolescents as an old courtship style. These results are in accordance with other studies which showed $12.1 \%$ of the respondents admitted to having experienced sexual intercourse (BKKBN, 2018a). Adolescents with low knowledge are 1.5 times more likely to engage in 
risky premarital sexual behavior, namely performing sexual intercourse by changing partners and/or without using condoms (Wulandari, 2016). This indicates that in addition to the risk of contracting Sexually Transmitted Infections (STI), their sexual behavior is also at risk for adverse or unexpected events.

Another factor that influences adolescents to have risky sexual behavior is parental supervision. Lack of supervision from parents is caused by parents who work hence enabling children to freely watch television without filtering the programs. Children's behavior is strongly influenced by their own and other people's experiences that they imitate both directly and through the media (Astarini, Hamid and Rustini, 2016).

Premarital sexual behavior is significantly related to access to pornography. Access to magazines, books, pornographic films, and action porn describing the pleasures of sex causes adolescents in their early stage to start trying to do so (Wulandari, 2016). As many as $60.6 \%$ of adolescents access pornography at least once a day with the majority using personal cellphone media (59.2\%) and doing it at home. In fact, $1.2 \%$ of adolescents began to be exposed to pornography since they were 5 to 8 years old (Gayatri, Shaluhiyah and Indraswari, 2020).

According to data from the Global School-based Health Survey (GSHS) in 2015, $5.26 \%$ of junior and senior high school students in Indonesia have had sex with only $13 \%$ of them using condoms. In addition, $27.35 \%$ of students have actively engaged in sexual intercourse under the age of 14 years (Kemenkes RI, 2016). According to Indonesian Demographic and Health Survey (IDHS), the percentage of adolescents who first had sexual intercourse at the age of 15 to 19 years increased from $59 \%$ in 2012 to $74 \%$ in 2017. As many as $6 \%$ of adolescents reported starting their first sexual experience at the age of 11 to 14 years which is the average age of early puberty and transition from childhood to adolescence (Badan Kependudukan dan Keluarga Berencana Nasional, 2018). These figures prove that there are greater risks and challenges in adolescent reproductive health problems if prevention is not immediately pursued before children get into their adolescence phase.

Every year approximately 16 million women aged 15 to 19 years and 2.5 million women aged under 16 years in developing countries experience labor (Ghose and John, 2017; Obare, Kabiru and Chandra-Mouli, 2018). According to the United Nations Development Economic and Social Affairs in 2010, Indonesia was the $37^{\text {th }}$ country with a high percentage of young marriages and was the second-highest in ASEAN after Cambodia. In 2010, there were 158 countries whose minimum legal age for marriage for women was 18 years old and over, but in Indonesia, the minimum age limit for women was 16 years. According to the Indonesian Demographic and Health Survey (IDHS), from 1991 to 2012, the age of young marriage increased every year (Kementrian Kesehatan RI, 2013).

Law Number 16 of 2019 amended Law Number 1 of 1974 on Marriage in which the minimum age for marriage became 19 years for men and women (UU RI no 16 Tahun 2019 tentang Perubahan atas UU no 1 Tahun 1974 tentang Perkawinan, 2019). Nevertheless, there is always a request for a marriage dispensation every year in court from the woman's parents accompanied by supporting evidence that urges immediate marriage under the age determined by law (Pengadilan Agama Klas 1.A Semarang, 2019).

Adolescent pregnancy can occur both in marriage and out of wedlock. Adolescents who are pregnant out of wedlock are faced with the choice of whether to continue their pregnancy or not, as well as the choice of getting married to cover the family's disgrace or not. Unexpected events that have occurred are more frequent to cause women to bear the physical and social consequences than men. The younger the age of the pregnant woman, the higher the health risks experienced by the baby and the mother. The immaturity of female reproductive organs under the age of 20 years causes health problems such as abortion and even maternal and 
child deaths due to pregnancy complications (Aprianti, Shaluhiyah and Suryoputro, 2018).

Female adolescents who choose to continue their pregnancy will tend to become both a mother and a wife with limitations in making decisions. The wife is very dependent on the husband in making decisions. While the husband himself is strongly influenced by his family to choose the decisions that will be made. This is especially frequent to happen to adolescent mothers in rural areas. As many as $64 \%$ of adolescents mothers do not work and depend on their husbands as well as husband's family for their lives which causes them not to have the freedom to make decisions. The mother's low personal autonomy has been reported to be the cause of the failure of exclusive breastfeeding. The dominant patriarchal culture also causes health problems such as determining family planning and controlling the number of children. Men still have more power than women to make decisions regarding maternal health. Whereas according to United Nations Population Fund (UNFPA) data, $72.2 \%$ of husbands have low knowledge regarding maternal health. In fact, $80.9 \%$ of husbands never asked about the results of their wife's pregnancy examination (Sutinah, 2017).

Continuing the pregnancy has both short and long-term health risks. Marriage at a young age is at risk because there are insufficient readiness in terms of health, mental-emotional, educational, socio-economic, and reproductive aspects (Sari, Umami and Darmawansyah, 2020). This has resulted in higher divorce rates and increased fertility rates (Fadlyana and Larasaty, 2016).

Marriage age is also related to birth control because the length of a woman's fertile period is related to the number of children born (Fadlyana and Larasaty, 2016; Ahiyanasari and Nurmala, 2018). The ideal age for first marriage for women according to the majority of female adolescents (37\%) aged 15 to 19 years is 24 to 25 , while according to the majority of male adolescents (33\%) is 20 to 21 years. The ideal age for first marriage for men according to most male adolescents $(49 \%)$ and female adolescents $(41 \%)$ is 24 to 25 years. However, there are still those who consider that the ideal age for first marriage is under 20 years, especially for women (Kementrian Kesehatan RI, 2013).

To prepare the design of health promotion programs, it is necessary to have a target-oriented need assessment hence the interventions implemented will be effective and efficient. Therefore, this study aims to determine the characteristics of Indonesian adolescents who have experienced pregnancy under the age of 20 years, thus reproductive health education strategies for prepubertal children can be designed by considering and adopting the findings of this study.

\section{METHOD}

This study used a cross-sectional design by processing the data from Basic Health Research 2018 of the Health Research and Development Agency of the Ministry of Health of the Republic of Indonesia. All respondents in this study were Indonesian women who had a history of pregnancy under the age of 20 years. There were 67,392 respondents who fit these criteria and all of them were used for further analysis in this study.

The independent variables of the study included the respondent's domicile, age, education level, and employment status. The dependent variable was age at first pregnancy. All variables were analyzed descriptively, bivariate relationship test with chi-square, and logistic regression test. This study used secondary data and was not carried out directly on humans, thus ethical clearance was not required in conducting the research.

\section{RESULTS AND DISCUSSION}

According to the data in Table 1 , it can be seen that most of the respondents live in rural areas (68.1\%), only graduated 
from primary school (38.7\%) with an almost evenly distributed age range between late adolescence and early elderly. This is very worrying because it entails a history of pregnancy at a young age occurs in each generation in large numbers, even though reproductive health programs have been carried out by the government and have improved since the International Conference for Population and Development (ICPD) in Cairo in 1994 (Prijatni and Rahayu, 2016).

A total of $47.9 \%$ of women who had been pregnant at the age of $<20$ years did not work while $24.9 \%$ worked as farmers. This is common because pregnant adolescents will always be in the most disadvantaged position. Adolescent pregnancies deprive young women of opportunities to continue their education and find better jobs. Adolescents who decide to continue their pregnancy and marry also have the responsibility to take care of their children as well as the household (Fluellen, 2016; Franjic, 2018; Sick, Spaulding and Park, 2018; Agnafors et al., 2019).

Almost all women in Indonesia (95.4\%) who had been pregnant at the age of $<20$ years experienced their first pregnancy at the age of 14 to 19 years. Pregnancy at that age is a high-risk pregnancy for its potential to endanger the safety of the mother and the fetus. This is due to the reproductive organs of women aged $<20$ years being not ready yet to carry a fetus than women aged 20 to 35 years (Govender, Naidoo and Taylor, 2019; Kiani, Ghazanfarpour and Saeidi, 2019).

The most worrying condition is that $4.6 \%$ of women in Indonesia had been pregnant at the age of $<14$ years. The average age of women in Indonesia getting into the puberty phase is 12.5 years (Wahab et al., 2018), which means $4.6 \%$ of women in Indonesia had been pregnant at the age of 12.5 to 14 years. At the latest, it only takes 1.5 years to get pregnant since the woman experiences menarche, which means sexual intercourse behavior has been carried out immediately after the woman gets her period or even before.
Table 1. Characteristics of Respondents

\begin{tabular}{lrr}
\hline \multicolumn{1}{c}{ Category } & $\mathbf{n}$ & $\%$ \\
\hline Domicile & & \\
\hline Urban area & 21,529 & 31.9 \\
Rural area & 45,863 & 68. \\
\hline Age & & \\
\hline Late adolescence & 8,752 & 13.0 \\
Early adulthood & 18,262 & 27. \\
Late adulthood & 22,200 & 32.9 \\
Early elderly & 18,178 & 27.0 \\
\hline Education Level & & \\
\hline Did not go to school & 4,189 & 6.2 \\
Did not graduate from & 11,659 & 17.3 \\
primary school & & \\
Graduated from primary & 26,091 & 38.7
\end{tabular}

school

Graduated from junior $\quad 15,844 \quad 23.5$

high school

Graduated from senior $\quad 8,686 \quad 12.9$

high school

Graduated from diploma $\quad 349 \quad 0.5$

$\begin{array}{lll}\text { Graduated from university } \quad 574 & 0.9\end{array}$

\begin{tabular}{lrr}
\hline Occupation & & \\
\hline Did not work & 32,267 & 47.9 \\
Student & 288 & 0.4 \\
PNS/TNI/POLRI/BUMN/BU & 419 & 0.6 \\
MD & & \\
Private employees & 1,577 & 2.3 \\
Entrepreneur & 7,328 & 10.9 \\
Farmer & 16,555 & 24.6 \\
Fisherman & 157 & 0.2 \\
Labor/driver/household & 3,178 & 4.7 \\
assistant & & \\
Other & 5,623 & 8.3 \\
\hline Age of Menarche & & \\
\hline$\leq 12$ years old & 73 & 0.1 \\
> 13 years old & 112 & 0.2 \\
Unsuitable & 67,207 & 99.7 \\
\hline Obstetric History & & \\
\end{tabular}

\begin{tabular}{lrr}
\hline Obstetric History & & \\
\hline Age at first pregnancy & & \\
$<14$ years old & 3,102 & 4.6 \\
14-19 years old & 64,290 & 95.4 \\
\hline Gravida & & \\
Primigravida & 8,868 & 13.2 \\
Multigravida & 51,227 & 76.0 \\
Grandemultigravida & 7,297 & 10.8 \\
\hline Paritas & & \\
Nullipara & 441 & 0.7 \\
Primipara & 10,136 & 15 \\
Multipara & 51,439 & 76.3 \\
Grandemultipara & 5,376 & 8 \\
\hline Abortion & & \\
Ever & 12,764 & 18.9 \\
Never & 54,628 & 81.1 \\
\hline Total & $\mathbf{6 7 , 3 9 2}$ & $\mathbf{1 0 0}$ \\
\hline
\end{tabular}

Based on the data from Basic Health Research 2018, it is known that there were $4.6 \%$ of female respondents 
who had been pregnant at the age of $<14$ years. This small percentage is very worrying and cannot be underestimated. If serious prevention efforts are not taken immediately, sexual intercourse is very likely to occur at a much younger age (Schoefield and Bierman, 2018). The low parental control over children and easy access to pornography make this prediction highly believed to occur (Ahanhanzo et al., 2018).

All respondents were in the age range of 14 to 54 years. The question regarding age of menarche was not asked to respondents aged above 20 years at the time of the survey. Thus, data on the age of menarche were only answered by less than $1 \%$ of respondents. This caused the variable age of menarche could not be tested for the relationship and its effect on the incidence of pregnancy in adolescents under the age of 20 years. However, it can be seen that there were 73 respondents who experienced their first menstruation at the age of 12 years, with the youngest was 8 years.

In addition to the age at first pregnancy, other obstetric histories were also known, namely the number of pregnancies (gravida), number of births (partum), and number of abortions (abortion). Most of the respondents (76\%) had been pregnant 2 to 5 times in their lifetime (multigravida) and $10.8 \%$ had experienced pregnancy more than 5 times. A total of $76.3 \%$ of respondents had a history of giving birth 2 to 5 times (multipara). As many as $18.9 \%$ claimed to have had an abortion, but it was not explained whether the type of abortion was spontaneous or provocative. From these data, it can be seen that there are still many Indonesian women who experience obstetric health risks.

The number of gravidas, parturitions, and abortions occurred after the first pregnancy thus these three cannot be the risk factors of the incidence of first pregnancy in women aged under 20 years. Therefore, the three variables above were only described descriptively in this study to strengthen the picture of Indonesian women who had been pregnant under the age of 20 years.

Table 2. Bivariate Test Result of Respondents' Characteristics who have Experienced Adolescent Pregnancy

\begin{tabular}{|c|c|c|c|c|c|c|c|}
\hline \multirow{3}{*}{ Variable } & \multicolumn{4}{|c|}{ Age of First Pregnant } & \multirow{2}{*}{\multicolumn{2}{|c|}{ Total }} & \multirow{3}{*}{ P-Value } \\
\hline & \multicolumn{2}{|c|}{$\begin{array}{l}<14 \text { Years } \\
\text { Old }\end{array}$} & \multicolumn{2}{|c|}{$\begin{array}{l}\text { 14-19 Years } \\
\text { Old }\end{array}$} & & & \\
\hline & $\mathrm{n}$ & $\%$ & $\mathbf{n}$ & $\%$ & $\mathbf{n}$ & $\%$ & \\
\hline \multicolumn{8}{|l|}{ Domicile } \\
\hline Urban area & 874 & 4.1 & 20,655 & 95.9 & 21,529 & 100 & \multirow{2}{*}{0.0001} \\
\hline Rural area & 2,228 & 4.9 & 43,635 & 95.1 & 45,863 & 100 & \\
\hline \multicolumn{8}{|l|}{ Age } \\
\hline Late adolescence & 219 & 2.5 & 8,533 & 97.5 & 8,752 & 100 & \multirow{4}{*}{0.0001} \\
\hline Early adulthood & 665 & 3.6 & 17,597 & 96.4 & 18,262 & 100 & \\
\hline Late adulthood & 1,082 & 4.9 & 21,118 & 95.1 & 22,200 & 100 & \\
\hline Early elderly & 1,136 & 6.2 & 17,042 & 93.8 & 18,178 & 100 & \\
\hline \multicolumn{8}{|l|}{ Education Level } \\
\hline Did not go to school & 338 & 8.1 & 3,851 & 91.9 & 4,189 & 100 & \multirow{7}{*}{0.0001} \\
\hline $\begin{array}{l}\text { Did not graduate from primary } \\
\text { school }\end{array}$ & 861 & 7.4 & 10,798 & 92.6 & 11,659 & 100 & \\
\hline $\begin{array}{l}\text { Graduated from primary } \\
\text { school }\end{array}$ & 1,354 & 5.2 & 24,737 & 94.8 & 26,091 & 100 & \\
\hline $\begin{array}{l}\text { Graduated from junior high } \\
\text { school }\end{array}$ & 358 & 2.3 & 15,486 & 97.7 & 15,844 & 100 & \\
\hline $\begin{array}{l}\text { Graduated from senior high } \\
\text { school }\end{array}$ & 155 & 1.8 & 8,531 & 98.2 & 8,686 & 100 & \\
\hline Graduated from diploma & 10 & 2.9 & 339 & 97.1 & 349 & 100 & \\
\hline Graduated from university & 26 & 4.5 & 548 & 95.5 & 574 & 100 & \\
\hline \multicolumn{8}{|l|}{ Occupation } \\
\hline Did not work & 1,357 & 4.2 & 30,910 & 95.8 & 32,267 & 100 & \multirow{6}{*}{0.0001} \\
\hline Student & 11 & 3.8 & 277 & 96.2 & 288 & 100 & \\
\hline PNS/TNI/POLRI/BUMN/BUMD & 17 & 4.1 & 402 & 95.9 & 419 & 100 & \\
\hline Private employees & 53 & 3.4 & 1,524 & 96.6 & 1,577 & 100 & \\
\hline Entrepreneur & 351 & 4.8 & 6,977 & 95.2 & 7,328 & 100 & \\
\hline Farmer & 907 & 5.5 & 15,648 & 94.5 & 16,555 & 100 & \\
\hline
\end{tabular}


164 Jurnal Promkes: The Indonesian Journal of Health Promotion and Health Education Vol. 9 No. 2, September 2021, 159-167 doi: 10.20473/jpk.V9.12.2021.159-167

\begin{tabular}{|c|c|c|c|c|c|c|c|}
\hline Fisherman & 11 & 7.0 & 146 & 93.0 & 157 & 100 & \\
\hline $\begin{array}{l}\text { Labor/driver/household } \\
\text { assistant }\end{array}$ & 151 & 4.8 & 3,027 & 95.2 & 3,178 & 100 & \\
\hline Other & 244 & 4.3 & 5,379 & 95.7 & 5,623 & 100 & \\
\hline \multicolumn{8}{|l|}{ Gravida } \\
\hline Primigravida & 279 & 3.1 & 8,589 & 96.9 & 8,868 & 100 & \multirow{3}{*}{0.0001} \\
\hline Multigravida & 2,261 & 4.4 & 48,966 & 95.6 & 51,227 & 100 & \\
\hline Grandemultigravida & 562 & 7.7 & 6,735 & 92.3 & 7,297 & 100 & \\
\hline \multicolumn{8}{|l|}{ Paritas } \\
\hline Nullipara & 28 & 6.3 & 413 & 93.7 & 441 & 100 & \multirow{4}{*}{0.0001} \\
\hline Primipara & 339 & 3.3 & 9,797 & 96.7 & 10,136 & 100 & \\
\hline Multipara & 2,300 & 4.5 & 49,139 & 95.5 & 51,439 & 100 & \\
\hline Grandemultipara & 435 & 8.1 & 4,941 & 91.9 & 5,376 & 100 & \\
\hline \multicolumn{8}{|l|}{ Abortion } \\
\hline Ever & 2,387 & 4.4 & 52,241 & 95.6 & 54,628 & 100 & \multirow[b]{2}{*}{0.0001} \\
\hline Never & 715 & 5.6 & 12,049 & 94.4 & 12,764 & 100 & \\
\hline
\end{tabular}

Table 3. Multivariate Test Result of Respondents' Characteristics who have Experienced Adolescent Pregnancy

\begin{tabular}{lcccccccc}
\hline \multicolumn{1}{c}{ Variable } & B & SE & Wald & df & Sig & \multirow{2}{*}{ Exp (B) } & \multicolumn{2}{c}{ 95\% Cl for Exp (B) } \\
\hline Domicile & -0.146 & 0.041 & 12.377 & 1 & 0.000 & 0.864 & 0.797 & 0.937 \\
Age & -0.262 & 0.020 & 170.923 & 1 & 0.000 & 0.769 & 0.740 & 0.800 \\
Education & 0.795 & 0.077 & 107.405 & 1 & 0.000 & 2.215 & 1.906 & 2.575 \\
Level & & & & & & & & \\
Occupation & -0.086 & 0.038 & 5.246 & 1 & 0.022 & 0.917 & 0.852 & 0.988 \\
\hline
\end{tabular}


There was a relationship between the respondent's domicile, age, education level, and occupation with the age at first pregnancy in adolescents who had experienced pregnancy during adolescence. Education was a variable that affected the age at first pregnancy with an OR value of 2.215. This means that adolescents with low education will be 2.2 times more likely to experience adolescent pregnancy at a younger age. The problems of education and adolescent pregnancy are like a vicious circle that continues to relate and influence each other. Pregnant women often have low education. After the school finds out about the pregnancy, they will be expelled from school which causes them not able to continue their education as their peers (Nkhoma et al., 2020; Tull, 2020). Continuing education can be done again later at an older age, but many women choose not to continue their education for reasons of taking care of their children and chose to work thus they can meet the needs of daily life rather than going to school. With low education, there is very small opportunity to get a job with a higher income (Shirin et al., 2016; Masuda and Yamauchi, 2017).

Pregnancy at a young age not only has short-term effects, but also long-term effects that adolescents and their families may not think about. Previous research has shown that women with low education were also at risk of having children who will behave the same way, namely having sexual intercourse in their adolescence (Cueto and Leon, 2016). As well as the vicious cycle between education and adolescent pregnancy, if this matter is not treated seriously, the problem of adolescent pregnancy will continue to recur and may cause a worse impact.

Indonesian society in general still holds a strongly patriarchal culture in living their social life. This system practices the position of men who often dominate, oppress, and exploit women. Patriarchy gives men more control over woman's bodies, sexuality, work, roles, and their status in the family as well as in society. In a social system that is strongly influenced by religion, patriarchy gives a rise to various forms of belief or ideology that men have a higher degree than women. This belief then forms a socio-cultural norm that places the ruling group with the ability to suppress weaker groups, in this case, the majority of women (Fakih, 2016;
BKKBN, 2018). Reproductive health education needs to consider social and cultural norms that run in Indonesia hence may be accepted and receive support from the surrounding environment. So far, the government is still focusing on reproductive health education whose target is the young. This is because health risks will more likely appear in the adolescence phase. This study showed that sexual intercourse behavior has been carried out by women in Indonesia as soon as they get their period. If the younger generation is not provided with reproductive health education at prepubertal age, the reproductive health education they receive as an adolescent will be less than optimal.

\section{CONCLUSION}

Adolescent pregnancy under the age of 20 years occurs in Indonesia every year. Most of the women who experienced pregnancy at a young age were pregnant at the age of 14 to 19 years, lived in rural areas, were in late adulthood at the time of the survey, had graduated from primary school, and did not work. There was a relationship between domicile, age, education level, and occupation on the first age of pregnancy of the adolescents. Education was a factor that affected the age of the first pregnancy.

The government needs to start to earnestly focus on addressing reproductive health problems in adolescents aged 9 to 11 years or before they get into their puberty phase. Providing provision of integrated reproductive health education with the school and family environment at an early age will be more promising to obtain optimal results than just trying to strive for prevention when they are already in their adolescence phase.

\section{ACKNOWLEDGMENT}

Thanks to the Indonesian Ministry of Health's National Institute of Health Research and Development (Balitbangkes) for giving permission to use the data of Basic Health Research 2018.

\section{REFERENCES}

Agnafors, S. et al. (2019) 'Mental health in young mothers, single mothers and their children', BMC Psychiatry, 
19(112).

Ahanhanzo, Y. G. et al. (2018) 'Factors associated with early sexual intercourse among teenagers and young adults in rural south of Benin', Journal of Public Health in Africa2, 9(2), pp. 88-91.

Ahiyanasari, C. E. and Nurmala, I. (2018) 'The intention of female high school students to prevent premarital sex', Jurnal PROMKES, 5(1), p. 39. doi: 10.20473/jpk.v5.i1.2017.39-52.

Aprianti, Shaluhiyah, Z. and Suryoputro, A. (2018) 'Fenomena Pernikahan Dini Membuat Orang Tua dan Remaja Tidak Takut Mengalami Kehamilan Tidak Diinginkan', Jurnal Promosi Kesehatan Indonesia, 13(1), pp. 61-73.

Astarini, N., Hamid, S. I. and Rustini, T. (2016) 'Studi Dampak Tayangan Televisi terhadap Perkembangan Perilaku Sosial Anak', Jurnal PGPAUD Kampus Cibiru, 4(2).

Badan Kependudukan dan Keluarga Berencana Nasional (2018) Survei Demografi dan Kesehatan Indonesia 2017: Buku Remaja. Jakarta. Available at:

https: / /archive.org/details/LaporanSD KI2017Remaja.

BKKBN (2018a) Survei Demografi dan Kesehatan Indonesia, Administrator SDKI.

BKKBN (2018b) Survei Demografi dan Kesehatan Indonesia 2017: Kesehatan Reproduksi Remaja (Indikator Utama). Jakarta: BKKBN. Available at: https://cis.bkkbn.go.id/latbang/?wpd mpro=indikator-utama-key-indicatorreport-kespro-remaja-sdki-2017_idhs2017_english-version.

Cueto, S. and Leon, J. (2016) 'Early Sexual Initiation among Adolescents: A Longitudinal Analysis for 15-years-olds in Peru', Interamerican Journal of Psychology, 50(2), pp. 186-203.

Fadlyana, E. and Larasaty, S. (2016) 'Pernikahan Usia Dini dan Permasalahannya', Sari Pediatri, 11(2), p. 136.

Fakih, M. (2016) Analisis Gender dan Transformasi Sosial. Yogyakarta: Insist Press.

Fluellen, J. L. (2016) Single Mothers of Young Children and Continuing Education. Walden University.

Franjic, S. (2018) 'Adolescent Pregnancy is a Serious Social Problem', Journal of Gynecological Research and
Obstetrics, April.

Gayatri, S., Shaluhiyah, Z. and Indraswari, R. (2020) 'Faktor-faktor yang Berhubungan dengan Frekuensi Akses Pornografi dan Dampaknya terhadap Perilaku Seksual pada Remaja di Kota Bogor', Jurnal Kesehatan Masyarakat, 8(3), pp. 410-19.

Ghose, S. and John, L. (2017) 'Adolescent Pregnancy: an overview', International Journal of Reproduction, Contraception, Obstetrics and Gynecology, 6(10), pp. 4197-4203.

Govender, D., Naidoo, S. and Taylor, M. (2019) 'Prevalence and Risk Factors of Repeat Pregnancy among South African Adolescent Females', African Journal of Reproductive Health, 23(1), pp. 7387.

Kemenkes RI (2016) Perilaku Berisiko Kesehatan pada Pelajar SMP dan SMA di Indonesia. Available at: https://www. who.int/ncds/surveillanc e/gshs/GSHS_2015_Indonesia_Report_ Bahasa.pdf?ua=1.

Kementrian Kesehatan RI (2013) 'Situasi Kesehatan Reproduksi Remaja', ISSN 2442-7659, pp. 1-6. doi: 24427659.

Kiani, M. A., Ghazanfarpour, M. and Saeidi, M. (2019) 'Adolescent Pregnancy: A Health Challenge', International Journal of Pediatrics, 7(7), pp. 9749-9752.

Masni and Hamid, S. F. (2018) 'Determinan Perilaku Seksual Berisiko pada Remaja Makassar (Studi Kasus Santri Darul Arqam Gombara dan SMAN 6)', Jurnal MKMI, 14(1), pp. 68-77.

Masuda, K. and Yamauchi, C. (2017) The Effects of Female Education on Adolescent Pregnancy and Child Health: Evidence from Uganda's Universal Primary Education for Fully Treated Cohorts. Tokyo.

Nkhoma, D. E. et al. (2020) 'Girls' Empowerment and Adolescent Pregnancy: A Systematic Review', International Journal of Environmental Research and Public Health, 17(1664), pp. 1-14.

Obare, F., Kabiru, C. and Chandra-Mouli, V. (2018) Reducing Early and Unintended Pregnancies among Adolescents. Geneva.

Pengadilan Agama Klas 1.A Semarang (2019) Laporan Pelaksanaan Kegiatan Tahun 2019. Semarang.

Prijatni, I. and Rahayu, S. (2016) Kesehatan Reproduksi dan Keluarga 
Berencana. 1st edn. Jakarta: Kemenkes RI.

Sari, L. Y., Umami, D. A. and Darmawansyah (2020) 'Dampak Pernikahan Dini Pada Kesehatan Reproduksi Dan Mental Perempuan (Studi Kasus Di Kecamatan Ilir Talo Kabupaten Seluma Provinsi Bengkulu)', Jurnal Bidang Ilmu Kesehatan, 10(1), pp. 53-65.

Schoefield, H.-L. T. and Bierman, K. L. (2018) 'Predicting Early Sexual Activity with Behavior Problems Exhibited at School Entry and in Early Adolescence', Journal of Abnormal Child Psychology, 36(8), pp. 11751188.

Shirin, F. et al. (2016) 'Adolescent Pregnancy: risk factors, outcome and prevention', Chattagram Maa-O-Shishu Hospital Medical College Journal, 15(1), pp. 53-56.

Sick, N., Spaulding, S. and Park, Y. (2018) Understanding Young Parent Families. Washington DC.
Sutinah (2017) 'Partisipasi Laki-laki dalam Program Keluarga Berencana di Era Masyarakat Postmodern', Jurnal Masyarakat, Kebudayaan dan Politik, 30(3), pp. 289-299.

Tull, K. (2020) Consequences for adolescents when they become pregnant, and become mothers. Brighton.

UU RI no 16 Tahun 2019 tentang Perubahan atas UU no 1 Tahun 1974 tentang Perkawinan (2019).

Wahab, A. et al. (2018) 'Declining age at menarche in Indonesia: a systematic review and meta-analysis', International Journal of Adolescent Medicine and Health, (September), pp. 1-9. doi: 10.1515/ijamh-2018-0021.

Wulandari, S. (2016) 'Perilaku Seksual Pranikah Berisiko terhadap Kehamilan Tidak Diinginkan pada Remaja SMKN Tandun Kabupaten Rokan Hulu', Jurnal Maternity and Neonatal, 2(2), pp. 7484. 